\title{
Correction to: The expression of HCV-associated host factors is dependent on the hepatoma cell line used in HCV studies
}

\author{
Thomas Walter Hoffmann ${ }^{1,2} \cdot$ Fabien Delfosse $^{2} \cdot$ François Helle $^{1} \cdot$ Catherine François $^{1,2} \cdot$ Gilles Duverlie $^{1,2}$. \\ Sandrine Castelain ${ }^{1,2}$
}

Published online: 27 September 2018

(c) Springer-Verlag GmbH Austria, part of Springer Nature 2018

\section{Correction to: Arch Virol (2014) 159:527-534 https://doi.org/10.1007/s00705-013-1862-9}

In this article, a clone of HepG2 stably expressing CD81 (HepG2-CD81) was used. Unfortunately, after cell line authentication, it appeared that this clone was misidentified and that these cells correspond in fact to HuH-7 cells [1]. The authors apologize for the confusion this misidentification might have caused even though it does not affect the main conclusions of the article.
The original article can be found online at https://doi.org/10.1007/ s00705-013-1862-9.

Sandrine Castelain

sandrine.castelain@u-picardie.fr

Thomas Walter Hoffmann

thomas.hoffmann@hotmail.fr

Fabien Delfosse

fabien.delfosse@nordnet.fr

François Helle

francois.helle@u-picardie.fr

Catherine François

catherine.francois@u-picardie.fr

Gilles Duverlie

gilles.duverlie@u-picardie.fr

1 EA4294 Unité de Virologie Clinique et Fondamentale, Université de Picardie Jules Verne, Amiens, France

2 Laboratoire de Virologie, Centre de Biologie Humaine, CHU-Hôpital Sud, Centre Hospitalier Universitaire d'Amiens, 80054 Amiens cedex, France

\section{Reference}

1. Belouzard S, Danneels A, Fénéant L, Séron K, Rouillé Y, Dubuisson J (2018) Correction for Belouzard et al., "Entry and Release of Hepatitis C Virus in Polarized Human Hepatocytes". J Virol 92(10):e00309-e00318 